\title{
41. STABLE ISOTOPE RATIOS IN DEEP SEA DRILLING PROJECT LEG 51 BASALTS
}

\author{
M. Javoy and A.M. Fouillac, Stable Isotope Geochemistry Laboratory, Departement of Earth Sciences and \\ LA 196 CNRS, University PARIS VII - 2, Place Jussieu 75005 Paris, France
}

\begin{abstract}
${ }^{18} \mathrm{O} /{ }^{16} \mathrm{O}$ and $\mathrm{D} / \mathrm{H}$ ratios have been measured on whole-rock samples from Holes 417A and 417D at sub-bottom depths of 200 to 400 meters. ${ }^{13} \mathrm{C}^{12} \mathrm{C}$ and ${ }^{18} \mathrm{O} /{ }^{16} \mathrm{O}$ ratios have been measured on the carbonate fraction of these rocks, and ${ }^{18} \mathrm{O} /{ }^{16} \mathrm{O}$ and $\mathrm{D} / \mathrm{H}$ on some smectite vein samples. The carbonate isotopic compositions vary from +25.4 to $29.6 \%$ for $\delta{ }^{18} \mathrm{O}$ SMOW and -4.9 to $+2.1 \%$ for $\delta{ }^{13} \mathrm{C} / \mathrm{PDB}$ and are fairly comparable for both holes. The $\delta{ }^{18} \mathrm{O}$ correspond to equilibrium temperatures of $17^{\circ} \mathrm{C}$ to $38^{\circ} \mathrm{C}$ with unmodified sea water, or lower if water has been substantially depleted in ${ }^{18} \mathrm{O}$. The $\delta{ }^{13} \mathrm{C}$ may be explained by mixtures in various proportions of primary carbonates with low-temperature-precipitated marine carbonate.

The $\delta^{18} \mathrm{O}$ of whole rocks vary from +6.5 to $+9.1 \%$ for Hole 417D and +6.7 to $+20.9 \%$ for Hole $417 \mathrm{~A}$. The correlation with $\mathrm{H}_{2} \mathrm{O}$ content indicates that essentially all the $\delta^{18} \mathrm{O}$ variations may be explained by a mixture of fresh basaltic material with increasing amounts of hydrated minerals of $\delta^{18} \mathrm{O}$ between +25 and $+27.5 \%$ formed at low temperatures. The degree of alteration varies from 7 to $22 \%$ for Hole $417 \mathrm{D}$ and 7 to $84 \%$ for Hole $417 \mathrm{~A}$.

The $\delta \mathrm{D}$ values $(-80$ to $-47 \%$, average of $-51 \%$ ) for Hole $417 \mathrm{~A}$ are compatible with low-temperature equilibrium with unmodified sea water of the 1:1 mixture of protoceladonite and smectite present in these rocks. The $\delta \mathrm{D}$ variations in Hole $417 \mathrm{D}(-81$ to $-64 \%$, average of $-73 \%$ ) indicate that water in equilibrium with saponite, the dominant hydrated mineral in this hole would be depleted by as much as $-26 \%$ relative to sea water. This is not explainable by simple isotopic evolution models of limited amounts of sea water in equilibrium with alteration products, since the water is always enriched relative to these products. These results rather imply that there is a significant contribution of deep-seated water in samples of Hole 417D.
\end{abstract}

\section{INTRODUCTION}

Oxygen isotope studies have been used extensively in studies of the alteration of ocean floor basalts (Garlick and Dymond, 1970; Muehlenbachs and Clayton, 1972; Pineau et al., 1976; Muehlenbachs, 1976, 1977). The ${ }^{18} \mathrm{O}$ content of these basalts is very sensitive to alteration and ${ }^{18} \mathrm{O} /{ }^{16} \mathrm{O}$ ratios are thus a simple index of the degree of alteration. Moreover, the ${ }^{18} \mathrm{O}$ composition of alteration products is temperature dependent so that such studies may also provide information on the thermal history of given portions of the oceanic crust. $\mathrm{D} / \mathrm{H}$ fractionations between minerals and water apparently vary little with temperature at temperatures lower than $400^{\circ} \mathrm{C}$ (Suzuoki and Epstein, 1976), but are very dependent on the chemical composition of hydroxyl-bearing phases. If the latter is known accurately, D/H ratios of hydroxyl-bearing minerals can give very useful information on the origin and proportions of the different water sources during the alteration. In the same way, the ${ }^{18} \mathrm{O}$ content of carbonates is a good temperature index, especially in the low temperature range, and the ${ }^{13} \mathrm{C}$ content may also give information on the origin of the carbonic species.
This methodology looked particularly promising in the study and comparison of rocks from Holes 417A and 417D of Leg 51 , where the alteration history apparently is very different for samples of 100-m.y.-old oceanic crust taken at a few hundred meters apart.

\section{ANALYTICAL PROCEDURE}

Oxygen is extracted from silicate rocks by bromine pentafluoride (Clayton and Mayeda, 1963) and reacted with carbon to give $\mathrm{CO}_{2} . \mathrm{CO}_{2}$ is extracted from carbonates by 100 per cent $\mathrm{H}_{3} \mathrm{PO}_{4}$ at $252^{\circ} \mathrm{C}$ (McCrea, 1950). Hydrogen, extracted mainly in the $\mathrm{H}_{2} \mathrm{O}$ form by fusion in an induction furnace, is obtained by reduction on uranium at $700^{\circ} \mathrm{C}$ (Bigeleisen et al., 1952). $\mathrm{CO}_{2}$ and $\mathrm{H}_{2}$ are then run on a 6-cm $90^{\circ}$ double-collecting mass spectrometer to give ${ }^{18} \mathrm{O} /{ }^{16} \mathrm{O}-{ }^{13} \mathrm{C} /{ }^{12} \mathrm{C}$ and $\mathrm{D} / \mathrm{H}$ ratios. The isotopic composition of a sample is given as:

$$
\delta_{\mathrm{E}}=\left(\frac{\mathrm{R}_{\mathrm{E}}}{\mathrm{R}_{\mathrm{Std}}}-1\right) \times 1000
$$


where $\mathrm{R}={ }^{18} \mathrm{O} /{ }^{16} \mathrm{O} /{ }^{13} \mathrm{C} /{ }^{12} \mathrm{C}$, or $\mathrm{D} / \mathrm{H}$ and the standard is SMOW for oxygen and hydrogen and PDB for carbon. The water and carbonate contents are determined in the same experiments.

\section{RESULTS AND DISCUSSION}

The results are given in Tables 1 and 2 . We can see that whole-rock $\delta^{18} \mathrm{O}$ vary from 6.5 to $9.1 \%$ for Hole $417 \mathrm{D}$ and from 6.7 to $20.9 \%$ for Hole $417 \mathrm{~A}$. Whole-rock $\mathrm{D} / \mathrm{H}$ vary between -47 and $-81 \%$ for Hole $417 \mathrm{~A}$ and -64 to -82 $\%$ for Hole 417D; water contents vary from 0.3 to 4.0 per cent and 0.5 to 1.0 per cent, respectively. Finally the $\delta^{18} \mathrm{O}$ of carbonates are very similar in both holes, ranging from 25.0 to $29.6 \%$. The $\delta^{13} \mathrm{C}$ vary from -3.4 to $+1.7 \%$ in Hole $417 \mathrm{~A}$ and -4.9 to $+2.1 \%$ in Hole $417 \mathrm{D}$.

\section{Whole-Rock $\delta^{18} \mathrm{O}$}

None of the variables is smoothly related to depth in the hole, as might be anticipated by petrological descriptions. However, if we plot whole-rock $\delta^{18} \mathrm{O}$ versus depth (Figure $1)$, there is a general increase with decreasing depth, with $\delta^{18} \mathrm{O}<7 \%$ below 300 meters. The $\delta^{18} \mathrm{O}$ of fresh MORB basalts is very constant between 5.5 and $5.7 \%$ (Muehlenbachs and Clayton, 1972); Pineau et al., 1976), and any departure from this range means alteration at low temperature if the $\delta^{18} \mathrm{O}$ increases, at medium or high temperature if it decreases. Thus, we see that all samples have been noticeably altered isotopically, but this alteration is much more conspicuous in Hole 417A samples, where only one sample corresponding to massive basalt-diabase transition has a $\delta^{18} \mathrm{O}$ of $7 \%$. A $\delta^{18} \mathrm{O}-\mathrm{H}_{2} \mathrm{O}^{+}$diagram (Figure 2) is an excellent way to relate $\delta^{18} \mathrm{O}$ variations to chemical alteration. There is a very good linear correlation, quite similar to those observed on mid-oceanic ridge basalts by the authors previously cited, except that for young basalts, the $\delta^{18} \mathrm{O}$ valuse rarely exceed $6.5 \%$. This correlation can be explained in terms of a simple two end-member mixing be- tween fresh basalt material and alteration products (palagonite, smectite). The analysis of smectite veins provides an estimate of the isotopic composition of the alteration products, which varies between 24.6 and $27.7 \%$. The hydrated products correspond to three main types of minerals: $\mathrm{Fe}$-rich protoceladonite, $\mathrm{Fe}-\mathrm{Mg}$ saponite, and $\mathrm{Al}$-rich smectite. Saponite is dominant in Hole 417D samples, whereas the average repartition in Hole $417 \mathrm{~A}$ is about a $1: 1 \mathrm{mix}$ of protoceladonite and Al-rich smectite corresponding to the alteration of plagioclase (C. Mevel and Y. Noach, personal communication). We do not have any precise mineralogical determination on the vein material isotopically analyzed, but the values do not differ very much from each other and they are characteristic of material produced at low temperature (Savin and Epstein, 1970). Depending on which $\delta^{18} \mathrm{O}$ value we choose for the upper end member, the degree of alteration in Hole 417D varies from 6 to 8 per cent, up to 17 to 22 per cent. Except for the bottom sample (7\%), the alteration is larger (26 to $40 \%$ ) in Hole $417 \mathrm{~A}$ and goes to a maximum of 66 to 84 per cent for the uppermost sample. In this preliminary study, we have not attempted to separate the more or less altered parts in a given sample so that these members represent the average alteration. The depth dependence would perhaps smoothen if we could find comparable samples (e.g., with a given glass content) in each core section. However, for comparable intermediate depths, we see that there is about $3.5 \%$ difference in $\delta^{18} \mathrm{O}$ between Holes $417 \mathrm{~A}$ and $417 \mathrm{D}$ (or about $16 \%$ more alteration). Thus, from an isotopic point of view (but closely related to chemical features), Hole $417 \mathrm{~A}$ is, on the average, about twice as altered as Hole $417 \mathrm{D}$ in the 220 to 300 -meter depth range.

\section{Carbonates}

The $\delta^{18} \mathrm{O}$ of the carbonate fraction provides a good estimate of the temperature of the alteration medium, although it may have equilibrated with water at temperatures different

TABLE 1

Isotopic Ratios in DSDP Leg 51 Basalts

\begin{tabular}{|c|c|c|c|c|c|c|c|}
\hline \multirow[b]{2}{*}{ Hole } & \multirow{2}{*}{$\begin{array}{c}\text { Sample } \\
\text { (Interval in cm) }\end{array}$} & \multirow[b]{2}{*}{$\delta^{18} \mathrm{O}_{\text {W.R/SMOW }}$} & \multirow[b]{2}{*}{${ }^{\delta} \mathrm{D}_{\mathrm{W} . \mathrm{R} / \mathrm{SMOW}}$} & \multirow{2}{*}{$\begin{array}{l}\mathrm{H}_{2} \mathrm{O}^{+} \\
(\%)\end{array}$} & \multicolumn{3}{|c|}{ Carbonates } \\
\hline & & & & & $(\%)$ & $\delta^{18} \mathrm{O}$ & ${ }^{13} \mathrm{C}$ \\
\hline $\begin{array}{c}417 \mathrm{~A} \\
\text { Whole Rocks }\end{array}$ & $\begin{array}{l}24-2,139-141 \\
25-2,11-15 \\
26-1,64-66 \\
30-5,64-67 \\
31-3,117-120 \\
44-3,8-10\end{array}$ & $\begin{array}{r}20.9 \\
11.3 \\
12.6 \\
11.8 \\
11.9 \\
6.7\end{array}$ & $\begin{array}{l}-52.5 \\
-47.4 \\
-50.1 \\
-67.5 \\
-53.4 \\
-80.7\end{array}$ & $\begin{array}{l}4.0 \\
2.0 \\
2.0 \\
2.0 \\
1.9 \\
0.3\end{array}$ & $\begin{array}{l}0.4 \\
9.0 \\
6.4 \\
0.02 \\
0.46 \\
0.03\end{array}$ & $\begin{array}{l}27.8 \\
28.3 \\
28.5 \\
28.2 \\
28.1 \\
25.0\end{array}$ & $\begin{array}{l}-1.9 \\
+1.7 \\
+1.3 \\
-3.1 \\
+2.3 \\
-3.4\end{array}$ \\
\hline $\begin{array}{c}\text { 417D } \\
\text { Whole Rocks }\end{array}$ & $\begin{array}{l}27-3,11-15 \\
27-5,16-19 \\
30-2,43-45 \\
31-1,94-96 \\
34-3,55-58 \\
41-5,110-115 \\
42-1,114-118 \\
43-6,77-82\end{array}$ & $\begin{array}{l}9.1 \\
7.5 \\
8.8 \\
8.9 \\
7.5 \\
6.5 \\
6.9 \\
7.0\end{array}$ & $\begin{array}{l}-72.7 \\
-81.6 \\
-71.6 \\
-71.5 \\
-76.2 \\
-73.3 \\
-74.5 \\
-64.0\end{array}$ & $\begin{array}{l}1.0 \\
0.6 \\
1.0 \\
1.0 \\
0.6 \\
0.6 \\
1.0 \\
0.5\end{array}$ & $\begin{array}{l}0.6 \\
0.6 \\
1.42 \\
0.24 \\
3.6 \\
0.04 \\
0.4 \\
3.0\end{array}$ & $\begin{array}{l}28.9 \\
26.1 \\
28.6 \\
25.7 \\
29.6 \\
26.1 \\
29.2 \\
28.3\end{array}$ & $\begin{array}{l}+2 \\
+1.1 \\
-1 \\
-0.5 \\
+2.1 \\
-1.8 \\
-4.9 \\
-0.1\end{array}$ \\
\hline $\begin{array}{c}\text { Smectite } \\
\text { Veins } \\
417 \mathrm{~A}\end{array}$ & $\begin{array}{l}28-2 \\
29-5 \\
30-1\end{array}$ & $\begin{array}{l}24.6 \\
26.9 \\
27.7\end{array}$ & $\begin{array}{l}-20.7 \\
-57.1 \\
-53.3\end{array}$ & $\begin{array}{l}8.4 \\
5.0 \\
-\end{array}$ & & & \\
\hline 417D & $\begin{array}{l}28-6 \\
37-3\end{array}$ & 27.8 & $\begin{array}{l}-68.2 \\
-65\end{array}$ & $\overline{2.4}$ & & & \\
\hline
\end{tabular}


TABLE 2

Summary Description of Samples Analyzed

\begin{tabular}{ll}
\hline $\begin{array}{c}\text { Sample } \\
\text { (Interval in cm) }\end{array}$ & \multicolumn{1}{c}{ Description } \\
\hline Hole 417A & \\
$24-2,139-141$ & Plagioclase porphyry basalt and palagonite tuff \\
$25-2,11-15$ & Porphyry basalt \\
$26-1,64-66$ & Porphyry basalt \\
$30-5,64-67$ & Porphyry basalt and volcanoclastics \\
$31-3,117-120$ & Porphyry basalt with amygdules \\
44-3, 8-10 & Transition porphyry basalt diabase \\
& \\
Hole 417D & \\
27-3,11-15 & Pillow fragments \\
27-5, 16-19 & Pillow fragments \\
$30-2,43-45$ & Plagioclase porphyry basalt \\
$31-1,94-96$ & Pillow fragments (plagioclase porphyry basalt) \\
$34-3,55-58$ & Dolerite \\
41-5, 110-115 & Pillow fragments (plagioclase porphyry basalt) \\
42-1, 114-118 & Pillow with plag. and cpx phenocrysts \\
43-6, 77-82 & Porphyry basalt \\
\hline
\end{tabular}

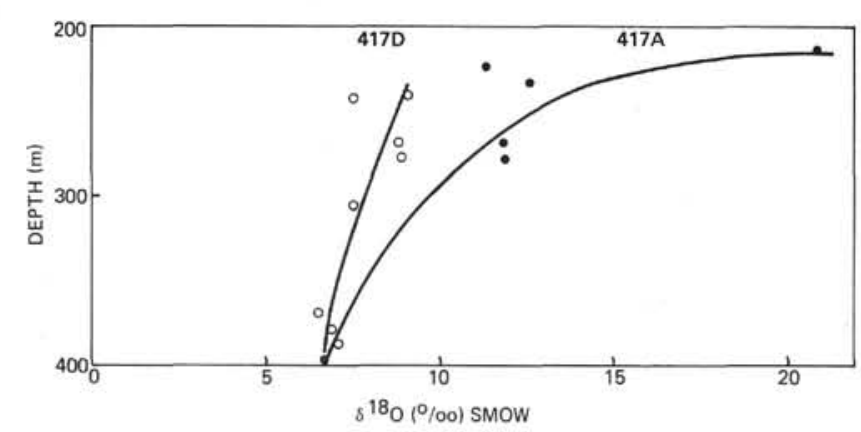

Figure 1. Plot of whole-rock $\delta^{18} \mathrm{O}$ versus sub-bottom depth.

from the other alteration products, or that the latter have not completely equilibrated with water. The carbonate isotopic temperatures vary between $17^{\circ} \mathrm{C}$ and $40^{\circ} \mathrm{C}$ (O'Neil et al., 1969) noticeably higher than the sea-bottom temperature. There is no significant difference between both holes and no correlation at all with the depth in the hole.

Of course, the given temperatures suppose that alteration water is unmodified sea water. Analysis of pore waters in Leg 8 and 15 samples by Lawrence et al. (1975) indicates that this is not the case in these legs; water $\delta^{18} \mathrm{O}$ is lowered by as much as $3 \%$ at depths between 100 and 400 meters. This would lower the isotopic temperatures to $7^{\circ}$ to $24^{\circ} \mathrm{C}$.

Some of the $\delta^{13} \mathrm{C}$ are clearly too low to correspond to carbonates in equilibrium with sea water bicarbonate ( 0 to $+4 \%$ ). In a $\delta^{13} \mathrm{C}-\delta^{18} \mathrm{O}$ diagram (Figure 3 ), these carbonates plot somewhere between "normal" low temperature marine carbonates and carbonic products $\left(\mathrm{CO}_{2}\right.$ or carbonates) of probable primary origin. It has been shown (Pineau et al., 1976) that some very fresh rocks of the FAMOUS area retained carbonic fluids and carbonate phases of primary origin. It may be that the $\mathrm{CO}_{2}$ recovered from acid attack corresponds to a mixture primary and secondary carbon. In a $\delta^{13} \mathrm{C}$-carbonate concentration plot (Figure 4), most samples fall along two curves which could be mixing lines corresponding to samples originally rich or poor in primary low $\delta^{13} \mathrm{C}$ (around $-8 \%$ ) carbon. Of course, any intermedi-

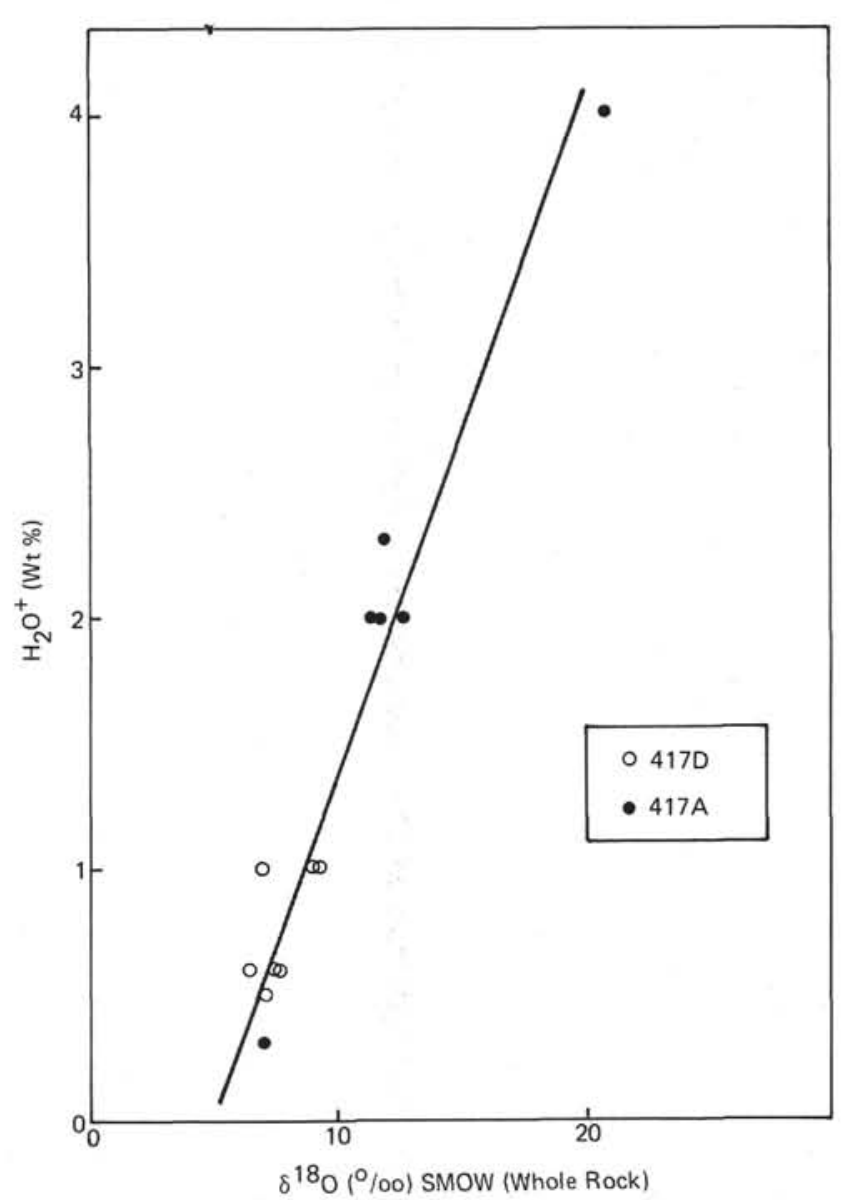

Figure 2. Correlation between whole-rock $\delta^{18} \mathrm{O}$ and $\mathrm{H}_{2} \mathrm{O}^{+}$ content (water extracted at $t>150^{\circ} \mathrm{C}$ in hydrogen analysis experiments).

ate curve is possible. Again, there is neither any difference between the two holes nor a correlation with depth.

\section{D/H Ratios}

With the exception of the bottom samples and an additional sample from each hole (i.e., with the exception of 25 to $30 \%$ of the samples under study), we see that the other $\delta$ D's in each hole are very similar and characteristic $(-51 \% 0$ and $-73 \%$ on the average). This difference $(20 \% 0)$ is large and remains significant $(14 \% 00)$, if we take all samples into account. According to Suzuoki and Epstein (1976), there should be very little variation of the fractionation coefficient between various hydrated minerals and water below $400^{\circ} \mathrm{C}$. On the contrary, there could be considerable variation due to the abundance variation of cations in octahedral coordination. If we take the results of $\mathrm{C}$. Mevel (personal communication) on protoceladonite, saponite, and plagioclase-derived smectite, and the equations given by Suzuoki and Epstein, we found fractionations with water of -66 , -47 , and $-29 \%$, respectively.

If, for Hole $417 \mathrm{~A}$, we take the average estimate of an equal proportion of protoceladonite and smectite, the resulting fractionation is $-47 \%$. The alteration water $(-6 \%)$ then has essentially the isotopic composition of unmodified sea water. The $-67.5 \%$ could correspond to pure celadonite, which has not been checked. The bottom 


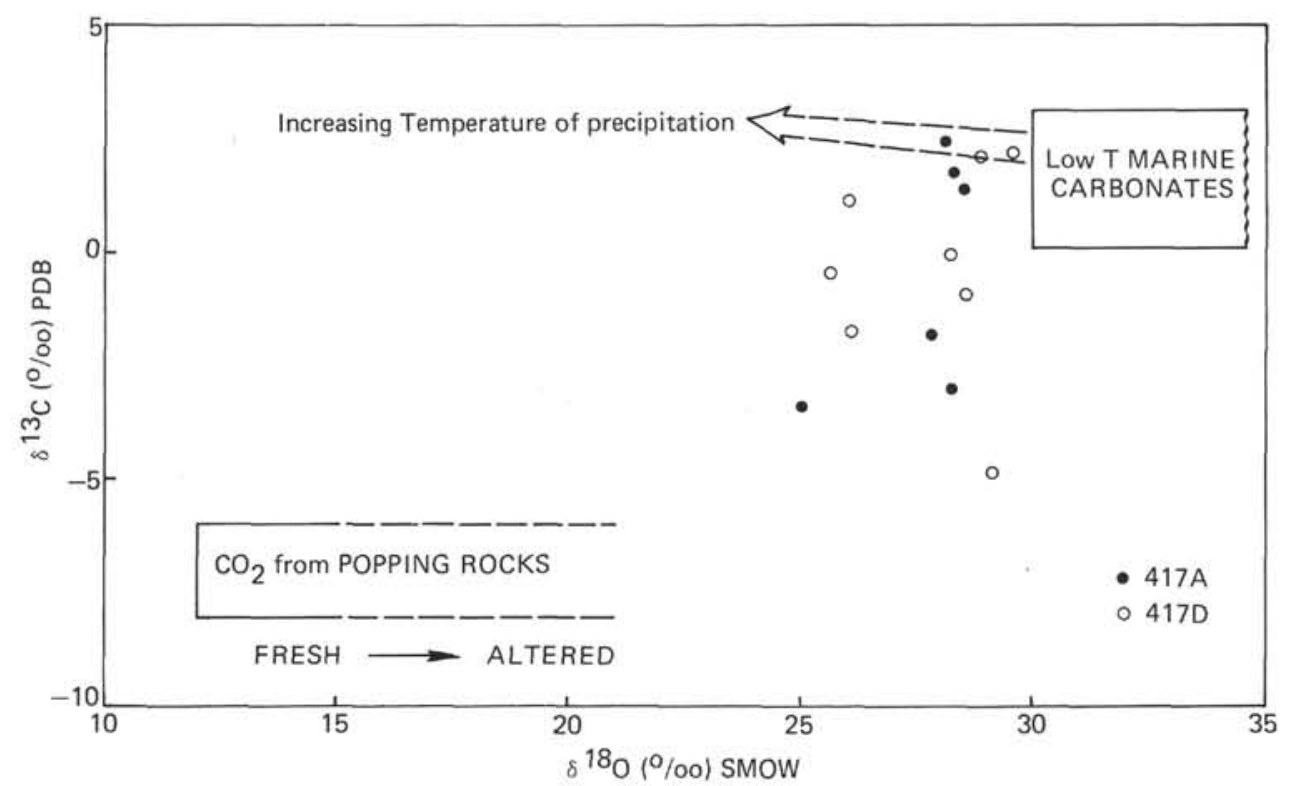

Figure 3. $\delta^{18} \mathrm{O}-\delta^{13} \mathrm{C}$ plot of carbonate phase analysis.

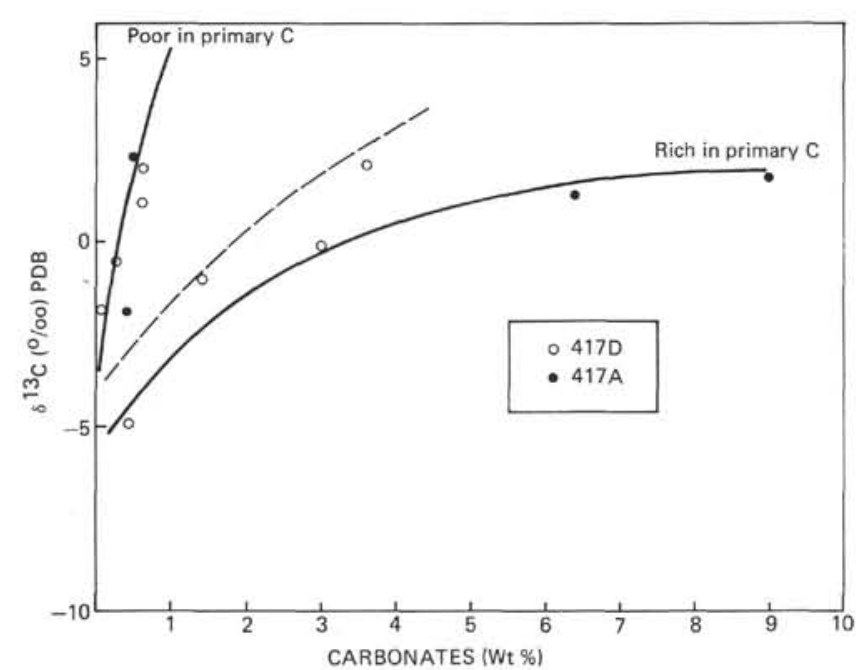

Figure 4. Correlation between $\delta^{13} \mathrm{C}$ of carbonates and carbonate content of the rock.

sample, with a $\delta \mathrm{D}$ of $-80.7 \%$, definitely cannot be explained by simple alteration with sea water. It must have retained a significant part of its deep-seated hydrogen record, which is likely in view of its low $\delta^{18} \mathrm{O}$.

The $\delta \mathrm{D}$ values in Hole $417 \mathrm{D}$ can definitely not be explained in the same way, the dominant alteration mineral in those rocks being saponite. The water in equilibrium with saponite at low temperature should have a $\delta \mathrm{D}$ of about $-26 \%$. The situation is not changed if we add various amounts of protoceladonite or plagioclase-derived smectite, or both. Returning to sea water values, we should have essentially pure celadonite, which is obviously not the case. Significant amounts of smectite make matters worse, since the fractionation with water is much lower. In fact, the most likely situation (that is, the existence of equivalent amounts of both minerals) gives a mean fractionation equal to that of saponite, and the problem remains to be solved. Following are two explanations:

1) The calibration at low temperature is not known and there are, in fact, significant variations with temperature below $400^{\circ} \mathrm{C}$. This could be true, but in the case of Hole $417 \mathrm{~A}$, we get to within $6 \%$ of unmodified sea water, which probably gives a good estimate of the error made in the calculation of the theoretical fractionation factor. Thus, we remain with a $20 \%$ depletion to explain. This cannot be explained in the same way as the ${ }^{18} \mathrm{O}$ depletions by Lawrence et al., since water is enriched in deuterium relative to all minerals and any evolution in finite reservoirs will lead to an increase in $\delta \mathrm{D}$ of water.

2) The more likely explanation is to consider that the samples of Hole 417D have retained some record of their primary hydrogen isotope composition and that the present values correspond to a mixture of primary and secondary hydrogen. This model is illustrated in Figure 5, where one can see that samples from both holes approximately fit mixing models between primary material $\left(\delta^{18} \mathrm{O}=5.7 \%\right.$, $\delta \mathrm{D}-80 \% 0$ ) and various alteration products represented by the vein materials. The $-20.7 \%$ value of the sample from Sections $417 \mathrm{~A}-28-2$ would closely approximate the plagioclase-derived smectite. The samples from Sections 417A29-5 and 417A-30-1 would correspond to a 1:1 mixture of celadonite and smectite. However, Hole 417D vein material barely corresponds to any mixture of these three components, so that some progress has to be made in quantitatively expressing this mixing model, particularly in getting good estimates of the amounts of various alteration products.

\section{CONCLUSION}

Essentially, all the isotope data on Holes 417A and 417D are consistent with the hypothesis of low temperature $\left(7^{\circ}\right.$ to $40^{\circ} \mathrm{C}$ ) alteration of both holes; the $417 \mathrm{~A}$ materials having, on the average, suffered twice as much alteration as 417D materials. Both holes seem to have retained some evidence 


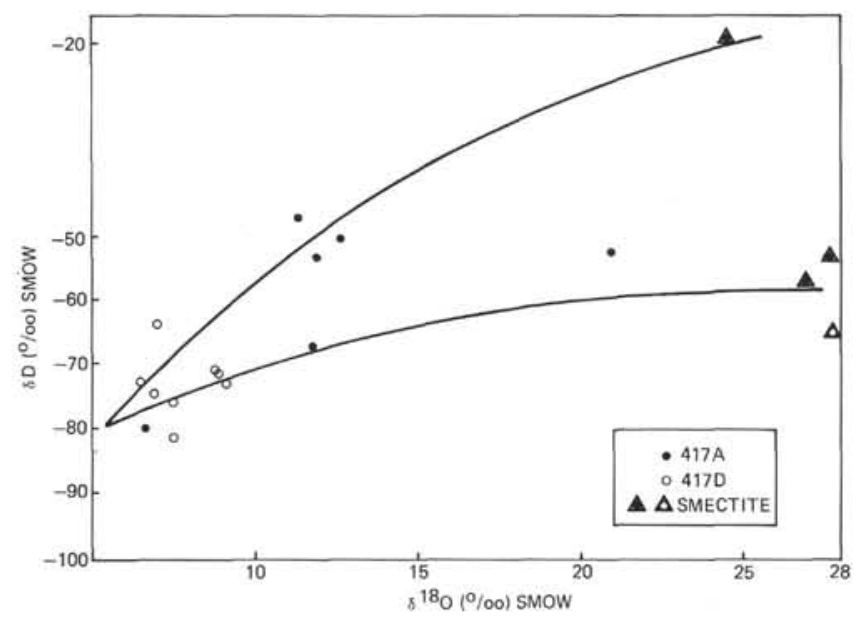

Figure 5. $\delta^{18} O-\delta D$ plot of whole-rock and smectite veins analyses.

of their primary carbon content and Hole 417D may have retained part of its primary hydrogen isotope record. Since the hydrogen isotope record is usually obliterated by low proportions of alteration water; this would mean that only limited amounts of water were allowed to circulate in the area of Hole 417D. This, in turn, means that the ${ }^{18} \mathrm{O}$ content of this water has been substantially lowered and that alteration temperature is, at least for this hole, lower than the values estimated from an open system model and close to sea bottom temperatures.

\section{ACKNOWLEDGMENTS}

Samples for this study were given by Y. Noach and C. Mevel who also provided information on the petrology and chemistry of alteration products.

\section{REFERENCES}

Bigeleisen, J., Perlman, M.L., and Prosser, H.C., 1952. Conversion of hydrogenic materials to hydrogen for isotopic analysis, Anal. Chem., v. 24, p. 1356.
Clayton, R.N. and Mayeda, T.K., 1963. The use of bromine pentafluoride in the extraction of oxygen from oxides and silicates for isotopic analysis, Geochim. Cosmochim. Acta, v. 27, p. 43-52.

Garlick, G.D. and Dymond, J.R., 1970. Oxygen isotope exchange between volcanic materials and ocean water, Geol. Soc. Am. Bull., v. 81 , p. $2137-2142$.

Lawrence, J.R., Gieskes, J.M., and Broecker, W.S., 1975. Oxygen isotope and cation composition of DSDP pore waters and the alteration of layer II basalts, Earth Planet. Sci. Lett., v. 27, p. $1-10$.

McCrea, J.M., 1950. On the isotopic chemistry of carbonates and a paleotemperature scale, J. Chem. Phys., v. 18, p. 849-857.

Muehlenbachs, K., 1976. Oxygen-isotope geochemistry of DSDP Leg 34 basalts. In Yeats, R.S. Hart, S.R., et al., Initial Reports of the Deep Sea Drilling Project, v. 34: Washington (U.S. Government Printing Office), p. 337-339.

, 1977. Oxygen isotope geochemistry of rocks from DSDP Leg 37 basalts, Canadian, J. Earth Sci., v. 14, p. 771-776.

Muehlenbachs, K. and Clayton, R.N., 1972. Oxygen isotope studies of fresh and weathered submarine basalts, Canadian J. Earth Sci., v. 9, p. 172-184.

O’Neil, J.R., Clayton, R.N., and Mayeda, T.K., 1970. Oxygen isotope fractionation in divalent metal carbonates, J. Chem. Phys., v. 51, p. 5547-5558.

Pineau, F., Javoy, M., and Bottinga, Y., 1976. ${ }^{13} \mathrm{C}^{12} \mathrm{C}$ ratios of rocks and inclusions in popping-rocks of the mid-atlantic ridge and their bearing on the problem of isotopic composition of deep-seated carbon, Earth Planet. Sci. Lett., v. 29, p. 413-421.

Pineau, F., Javoy, M., Hawkins, J.W., and Craig, H., 1976. Oxygen isotope variations in marginal basins and ocean ridge basalts, Earth Planet. Sci. Lett., v. 28, p. 299-307.

Savin, S.M. and Epstein, S., 1970. The oxygen and hydrogen isotope geochemistry of ocean sediments and shales, Geochim. Cosmochim. Acta, v. 34, p. 43-63.

Suzuoki, T. and Epstein, S. 1976. Hydrogen isotope fractionation between $\mathrm{OH}$-bearing silicate minerals and water, Geochim. Cosmochim. Acta, v. 40, p. 1229-1240. 